\title{
Physical and Chemical Characteristics of Betok Fish (Anabas testudineus) from Swamp Water in South Sumatera, Indonesia
}

\author{
Merynda Indriyani Syafutri ${ }^{1, *}$, Mirna Fitrani ${ }^{1}$, Friska Syaiful ${ }^{1}$, and Imfrantoni Purba ${ }^{1}$ \\ ${ }^{1}$ Faculty of Agriculture, Universitas Sriwijaya, South Sumatra, Indonesia
}

\begin{abstract}
Betok (Anabas testudineus) is one of freshwater fish species locally of Indonesia. It has economic value and potential to be developed as a source of protein. The aimed of this research was to analyze the physical and chemical characteristics of the Betok fish from the swamp waters in South Sumatera. This research used descriptive method. Fish samples were taken from four locations of swamp water in South Sumatera (Palembang, Banyuasin, Ogan Komering Ilir, and Musi Banyuasin). The result showed that Betok fish from swamp water of South Sumatera had total length 10.0 to $11.5 \mathrm{~cm}$. Length, width, and weight of Betok fish were 8.0 to $9.0 \mathrm{~cm}, 3.0$ to $4.0 \mathrm{~cm}$, and 23.08 to $30.93 \mathrm{~g}$, respectively. The Betok fish had dark color. The chemical characteristics of Betok fish were 66.18 to $74.98 \%$ of moisture content, 5.08 to $6.79 \%$ of ash, 11.22 to $19.46 \%$ of protein, 0.82 to $3.48 \%$ of fat, and 1.03 to $12.05 \%$ of carbohydrate. The dominant amino acids of Betok fish were glutamic acid and glycine, while the dominant fatty acids were oleic acid and palmitic acid. Heavy metals content of Betok fish from swamp water of South Sumatra was still below the maximum level.
\end{abstract}

\section{Introduction}

Swamp is land that its water regime is affected by the rain, which fell in the local area or in the surrounding area and upstream. Swamp lowland divided into 3 parts, namely shallow swamp (puddle of water is less than $50 \mathrm{~cm}$ for $<3$ months), middle swamp (puddle of water is between 50 to $100 \mathrm{~cm}$ for 3 to 6 months), and deep swamp (a pool of water more than $100 \mathrm{~cm}$ for $>6$ months) [1]. In Indonesia, swamp land scattered in several areas such as Sumatera, Kalimantan and Papua. It is about 33 million hectares.

South Sumatera is one of provinces in Indonesia which has wide swamp land. Tidal swamp land in South Sumatera amounted to 455.949 hectares, while the lowland swamp land in South Sumatera amounted to 157.846 [2]. Swamp land in South Sumatera are in Palembang, Musi Banyuasin, Banyuasin, Ogan Komering Ilir, Muara Enim, Ogan Ilir, and East OKU. Swamp conditions in South Sumatera are very diverse, ranging from tidal, lowland, and peat bog. Each of swamp land has different characteristics (water quality,

\footnotetext{
* Corresponding author: misyafutri@gmail.com / misyafutri@fp.unsri.ac.id
} 
physical, chemical and biology). The difference of water characteristics will cause the difference of organism type, including fish, that live in swamp water.

Betok (Anabas testudineus) is one of freshwater fish species locally of Indonesia. It is widely available in lake, river, swamp and brackish water. This species is spread in Kalimantan, Sumatra and Java [3]. Betok has economic value and potential to be developed as a source of protein. There are four families of swamp fish that valued economically namely Anabantidae, Channidae, Claridae, and Syinbranchidae [4]. One type of fish from Anabantidae that have economic value is Betok (genus Anabas). Betok have additional breathing apparatus called labyrinth [5], so it able to live in swamp water with extreme condition.

The level of nutrients and heavy metals that be contained in swamp fish body is important to be known. The condition of water, such as the physical, chemical and biological of water, could influence the characteristics of fish [6]. Therefore, it is necessary to do research on the physical and chemical characteristics of Betok fish that live in the swamp water of South Sumatera.

\section{Materials and Methods}

The method used in this research was descriptive method. Betok fish samples obtained from four locations of swamp water in South Sumatera (Palembang, Banyuasin, Ogan Komering Ilir, and Musi Banyuasin). At each location, 10 adult fishes were taken. That fishes were put in a container filled with water and taken to the laboratory.

The data of physical and chemical characteristics of Betok fish obtained by analysis in the laboratories. Analysis of physical characteristic of Betok fish was conducted in the Pusdata Rawa Laboratory Palembang, while analysis of chemical characteristic of Betok fish was conducted in the Laboratory of Chemical Agriculture, Faculty of Agriculture Universitas Sriwijaya Palembang and Integrated Laboratory of IPB. Heavy metal analysis was conducted in Baristand Laboratory Palembang. The data were presented in tables.

Physical Characteristics

The physical characteristics of fish were morphology of fish included total length, length, weight, width, and color of Betok fish. The total length of fish was a total body length of fish that measured starting from the leading edge up to the last part of the body of fish (tails). Measuring the length and width of fish body using a ruler, while measuring the weight of fish body using analytical scale. Fish color measurement was done visually.

Chemical Characteristics

The chemical characteristics consisted of moisture content, ash, protein, fat, carbohydrate, amino acids, and fatty acids of Betok fish [7]. Heavy metals (Fe, Cd, Pb) referred to SNI 2354.5:2011.

\section{Results and Discussions}

\subsection{Physical Characteristics}

Betok (Anabas testudineus) is one of the potentially fish in the swamp water of South Sumatera. The physical characteristics of Betok fish that lived in swamp waters of South Sumatera included total length, length, weight, width and color of body of fish. The total length of Betok fish was in the range of 10.0 to $11.5 \mathrm{~cm}$, while the length of Betok fish was in the range of 8.0 to $9.0 \mathrm{~cm}$. Betok fish had width of body 3.0 to $4.0 \mathrm{~cm}$ and weight of body 23.08 to $30.93 \mathrm{~g}$ (Table 1 ). 
The length, total length and weight values of Betok fish from this research similar to the previous research which stated that the length and the weight of Betok fish ranged from 8.5 to $14.5 \mathrm{~cm}$ and 10.0 to $50.0 \mathrm{~g}$, respectively [8]. The Betok fish including a medium-sized fish. The Betok fish had the maximum lenght of about $23 \mathrm{~cm}$ and weight of about 200 $\mathrm{g} /$ head. The Betok fish had a growth pattern allometric. The long growth balanced with weight growth, so the body shape of the Betok fish tend to be symmetrical, not too long and also not too fat $[8,9]$.

The Betok fish had the dark gray to black color (dark color). The Betok fish from swamp water of South Sumatera presented on Figure 1. The color of Betok fish from swamp water of South Sumatera was dark generally. According to previous research, Betok fish classified the blackfishes group [4]. The color of Betok fish was gray to greenish, with a black spot at the base of the tail [5].

Table 1. The physical characteristics of Betok fish from swamp water of South Sumatera

\begin{tabular}{|c|c|}
\hline Physical Characteristics & Size \\
\hline Total Length $(\mathrm{cm})$ & $10.0-11.5$ \\
\hline Length $(\mathrm{cm})$ & $8.0-9.0$ \\
\hline Width $(\mathrm{cm})$ & $3.0-4.0$ \\
\hline Weight $(\mathrm{gram})$ & $23.08-30.93$ \\
\hline
\end{tabular}

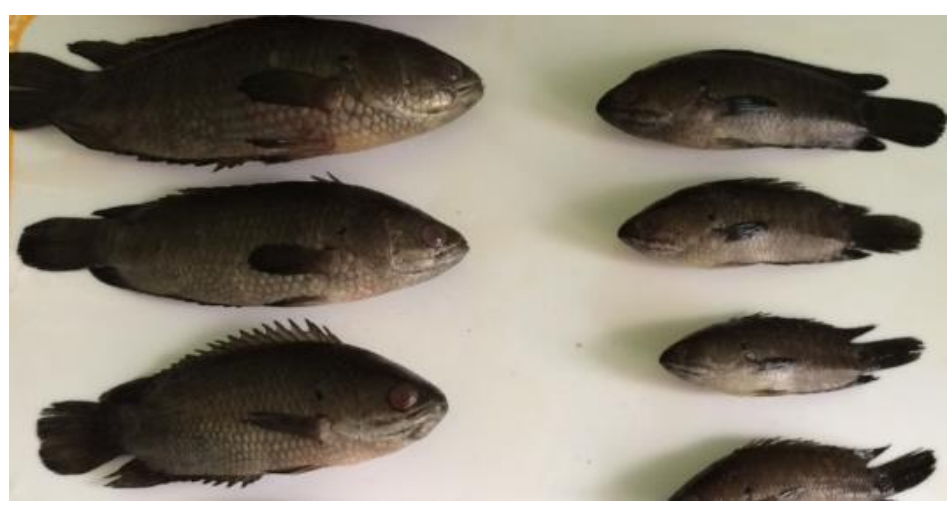

Fig. 1. Betok fish from swamp water of South Sumatera

\subsection{Chemical Characteristics}

The chemical characteristics of Betok fish from swamp water of South Sumatera included moisture, ash, protein, fat, carbohydrate content, amino acids, and fatty acids (Table 2, 3, and 4). The results showed that the moisture content of Betok fish was in the range of 66.18 to $74.98 \%$, while the ash content of Betok fish was in the range of 5.08 to $6.79 \%$. The protein content of Betok fish in the range of 11.22 to $19.46 \%$, while the fat content of Betok fish in the range of 0.82 to $3.48 \%$. The Betok fish contained 1.03 to $12.05 \%$ of carbohydrate.

Betok fish from swamp water of South Sumatera had the moisture and fat content values in accordance with the moisture and fat content in the fish generally. Fish contained 60.0 to $80.0 \%$ of moisture content, 16.0 to $30.0 \%$ of protein content, 0.7 to $4.8 \%$ of fat content, and 0.0 to $1.0 \%$ of carbohydrate content[10,11,12]. Betok fish contains $75 \%$ of 
moisture content, $1.2 \%$ of ash content, $14.3 \%$ of protein content, $4.9 \%$ of fat content and $4.6 \%$ of carbohydrate content [13]. Those nutrient values were not much different from some of nutrient values of Betok fish.

Betok fish from swamp water of South Sumatera contained $9.99 \%$ of total amino acid. The dominant amino acids of Betok fish were glutamic acid and glycine. Glutamic acid and glycine were non-essential amino acids. Non-essential amino acids are amino acids that can be synthesized by the body through reductive aminase of ketone acids or through transaminases [14]. The dominant essential amino acids (amino acids that cannot be synthesized by the body) of Betok fish were leucine $(0.75 \%)$, lysine $(0.75 \%)$, and arginine $(0.71 \%)$.

Table 2. The chemical characteristics of Betok fish from swamp water of South Sumatera

\begin{tabular}{|c|c|}
\hline Chemical Characteristics & Total \\
\hline Moisture content (\%) & $66.18-74.98$ \\
\hline Ash content (\%) & $5.08-6.79$ \\
\hline Protein content (\%) & $11.22-19.46$ \\
\hline Fat content (\%) & $0.82-3.48$ \\
\hline Carbohydrate content (\%) & $1.03-12.05$ \\
\hline
\end{tabular}

Table 3. The amino acid content of the Betok fish from the swamp water of South Sumatra

\begin{tabular}{|c|c|}
\hline Amino Acids & Total (\%) \\
\hline Aspartic acid & 0.95 \\
\hline Glutamic acid & 1.63 \\
\hline Serine & 0.49 \\
\hline Histidine & 0.18 \\
\hline Glycine & 1.32 \\
\hline Threonine & 0.44 \\
\hline Arginine & 0.71 \\
\hline Alanine & 0.94 \\
\hline Tyrosine & 0.28 \\
\hline Methionine & 0.25 \\
\hline Valine & 0.49 \\
\hline Phenylalanine & 0.41 \\
\hline I-leucine & 0.41 \\
\hline Leucine & 0.75 \\
\hline Lysine & 0.75 \\
\hline Amino Acid Total & 9.99 \\
\hline
\end{tabular}

Betok fish also contained some fatty acids that the body needs. The total fatty acid content of Betok fish was $48.58 \%$. The dominant fatty acids of Betok fish were oleic acid and palmitic acid. Oleic acid is a monounsaturated fatty acid, while palmitic acid is a saturated fatty acid. Palmitic acid is the most saturated fatty acid that be found in food, which is 15 to $50 \%[14,15]$. Betok fish from the swamp water of South Sumatra also contained essential fatty acids, namely linoleic acid (4.04\%). 
The heavy metals content in the body of Betok fish included $\mathrm{Fe}, \mathrm{Cd}$, and $\mathrm{Pb}$. The heavy metals content found in the body of the fish come from the swamp water where Betok fish live. The occurrence of pollution in the water will interfere the life of the aquatic organisms [16]. The presence of heavy metals in swamp areas also could be obtained from the air (from vehicles emission and land fire) [17]. The results showed that Betok fish from the swamp water of South Sumatra contained 8.57 to $60.31 \mathrm{mg} / \mathrm{kg}$ of Fe, $<0.005$ to 0.029 $\mathrm{mg} / \mathrm{kg}$ of $\mathrm{Cd}$, and 0.029 to $0.270 \mathrm{mg} / \mathrm{kg}$ of $\mathrm{Pb}$. The maximum level of $\mathrm{Pb}$ found in processed fish product is $0.3 \mathrm{mg} / \mathrm{kg}$ [18].

Table 4. The fatty acid content of the Betok fish from the swamp water of South Sumatra

\begin{tabular}{|c|c|}
\hline Fatty Acids & Total (\%) \\
\hline Lauric Acid & 0.04 \\
\hline Myristic Acid & 0.50 \\
\hline Pentadecanoic Acid & 0.14 \\
\hline Palmitic Acid & 10.22 \\
\hline Palmitoleic Acid & 2.99 \\
\hline Heptadecanoic Acid & 0.26 \\
\hline Cis-10-Heptadecanoic Acid & 0.16 \\
\hline Stearic Acid & 4.10 \\
\hline Elaidic Acid & 0.12 \\
\hline Oleic Acid & 21.71 \\
\hline Linoleic Acid & 4.04 \\
\hline Arachidic Acid & 0.18 \\
\hline$\gamma$-Linolenic Acid & 0.23 \\
\hline Cis-11-Eicosenoic Acid & 1.46 \\
\hline Cis-11,14-Eicosedienoic Acid & 0.15 \\
\hline Cis-8,11,14-Eicosetrienoic Acid & 0.32 \\
\hline Arachidonic Acid & 1.01 \\
\hline Tricosanoic Acid & 0.02 \\
\hline Cis-5,8,11,14,17-Eicosapentaenoic Acid & 0.10 \\
\hline Cis-4,7,10,13,16,19-Docosahexaenoic Acid & 0.83 \\
\hline Fatty Acid Total & 48.58 \\
\hline
\end{tabular}

\section{Conclusions}

Betok fish from swamp water of South Sumatera including a medium-sized fish. Betok fish had total length 10.0 to $11.5 \mathrm{~cm}$, length 8.0 to $9.0 \mathrm{~cm}$, width 3.0 to $4.0 \mathrm{~cm}$, weight 23.08 to $30.93 \mathrm{~g}$, and dark color. Betok fish contained 66.18 to $74.98 \%$ of moisture content, 5.08 to $6.79 \%$ of ash content, 11.22 to $19.46 \%$ of protein content, 0.82 to $3.48 \%$ of fat content, and 1.03 to $12.05 \%$ of carbohydrate content. The dominant amino acids of Betok fish were glutamic acid and glycine, while the dominant fatty acids were oleic acid and palmitic acid. Heavy metals content of Betok fish from swamp water of South Sumatra was still below the maximum level.

\section{References}

1. W. Sudana. J. Analisis Kebijakan Pertanian 3, 2 (2005)

2. Biro Pusat Statistika (BPS), Land Areaaccording to Its Usein South Sumatera. (Palembang, 2007) 
3. A. Murjani. Performancegrowth of somevarietiesof Betok fishreared inswampwaters. Jurnal Ilmiah Ilmu-ilmu Pertanian 7, 2 (2011)

4. Muslim.The kinds ofswampeconomically valuablefish (Research Report) (Faculty of Agriculture, Sriwijaya University, Indralaya, 2007)

5. D.N. Pandit, T.K. Ghosh. Journal of Environment Biology 28, 1 (2007)

6. N.B.W. Mufidah, B.S. Rahardja, W.H. Jurnal Ilmiah Perikanan dan Kelautan 1, 1 (2009)

7. AOAC. Official Methods od An Anlysis of Analysis Chemistry (Washington DC. United Stated of America, 2006)

8. M. Fitrani, Muslim, D. J. Agria 7, 1 (2011)

9. M.G.H. Kordi. FarmBigbook-Fish Culture ConsumptioninFreshwater (LilyPublisher, Yogyakarta, 2013)

10. A. Khomsan. Fish, Health Food and NutritionRichin TheRole ofFood and Nutritionfor theQuality of Life (GramediaWidiasarana, Jakarta, 2004)

11. Suhartini, Hidayat, Processed Fresh Fish. Penerbit Trubus Agri Sarana (Surabaya, 2005)

12. Ditjen P2HPMovementpromoteeating fish, Satker Direktorat Pengolahan Hasil, (Jakarta, 2007)

13. Nutritionist Associationof Indonesia, IndonesianFoodComposition Table (Elex Media Komputindo, Jakarta, 2009)

14. S. Almatsier, Basic Principles of Nutritional Sciences (Gramedia Pustaka Utama, Jakarta, 2003)

15. F.G. Winarno, Food Chemistry and Nutrition (Gramedia Pustaka Utama, Jakarta, 2004)

16. J.Y.M. Alkassasbeh, L.Y. Heng, S. Surif . American Journal of Environment 5, 3 (2009)

17. Environmental Research Center (PPLH) IPB, Study of the Potential of the Waters Area of Jakarta Bay (PPLH IPB Research Institute, Bogor, 1997)

18. Food and Drug Supervisory Agency (BPOM), Maximum Types and Limits of Heavy Metal Contamination in Food (Department of Health, Jakarta, 2009) 